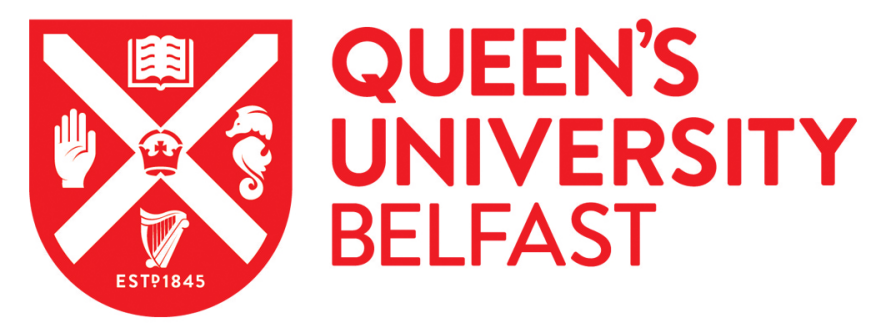

\title{
Removal of androgens and estrogens from water by reactive materials
}

Cai, K., Phillips, D. H., Elliott, C., Van Der Heiden, E., Scippo, M-L., Muller, M., \& Connolly, L. (2010). Removal of androgens and estrogens from water by reactive materials. Journal of Water Research and Protection, 2(11), 990-993. https://doi.org/10.4236/jwarp.2010.211118

\section{Published in:}

Journal of Water Research and Protection

\section{Document Version:}

Publisher's PDF, also known as Version of record

\section{Queen's University Belfast - Research Portal:}

Link to publication record in Queen's University Belfast Research Portal

\section{Publisher rights}

Copyright 2010 The Authors and Journal of Water Resource and Protection.

This is an open access article published under a Creative Commons Attribution License (https://creativecommons.org/licenses/by/4.0/), which permits unrestricted use, distribution and reproduction in any medium, provided the author and source are cited.

\section{General rights}

Copyright for the publications made accessible via the Queen's University Belfast Research Portal is retained by the author(s) and / or other copyright owners and it is a condition of accessing these publications that users recognise and abide by the legal requirements associated with these rights.

Take down policy

The Research Portal is Queen's institutional repository that provides access to Queen's research output. Every effort has been made to ensure that content in the Research Portal does not infringe any person's rights, or applicable UK laws. If you discover content in the Research Portal that you believe breaches copyright or violates any law, please contact openaccess@qub.ac.uk. 


\title{
Removal of Androgens and Estrogens from Water by Reactive Materials"
}

\author{
Kai Cai ${ }^{1}$, Debra H. Phillips ${ }^{2}$, Chris Elliott ${ }^{1}$, Edwige Van der Heiden ${ }^{3}$, Marie-Louise Scippo ${ }^{3}$, \\ Marc Muller ${ }^{4}$, Lisa Connolly ${ }^{1}$ \\ ${ }^{1}$ The Institute of Agri-Food and Land Use, Queen's University Belfast, Northern Ireland \\ ${ }^{2}$ Environmental Engineering Research Centre, School of Planning, Architecture \& Civil Engineering, Queen's Univer- \\ sity Belfast, Belfast, Northern Ireland \\ ${ }^{3}$ Department of Food Sciences, University of Liege, Liege, Belgium \\ ${ }^{4}$ Genetics and Molecular Biology Department, University of Liege, Liege, Belgium \\ E-mail:ckai01@qub.ac.uk \\ Received August 27, 2010; revised October 11, 2010; accepted October 21, 2010
}

\begin{abstract}
Nowadays, endocrine disruptor compounds in the water system have become a concern due to the risk of contamination to wild life and humans even at the nanogram level. Excess estrogens and androgens are a major contributor group of endocrine compounds. Statistical surveys have shown that dairy farms contribute to over $90 \%$ of the total estrogens in the UK and US. Reporter gene assays (RGAs) is being developed to assess the efficiency of reactive materials to remove target hormonal contaminants from dairy farm wastewater. This study demonstrates that $2 \mathrm{~g}$ of reactive materials (granular activated carbon (GAC), zero-valent iron (ZVI) and organoclay) efficiently removed over $50 \%$ of $17 \beta$-estradiol and $92 \%$ Testosterone over a $24 \mathrm{~h}$ period from $20 \mathrm{ml}$ of HPLC grade water spiked at a concentration of $1000 \mathrm{ng} \mathrm{l}^{-1}$. Therefore, these materials may be useful adsorbents for the advanced treatment of residual natural hormones in dairy farm wastewater.
\end{abstract}

Keywords: Dairy Farm Wastewater, Natural Hormones, Reactive Materials, Reporter Gene Assay

\section{Introduction}

Over the past twenty years, considerable scientific concerns and public debate have been expressed over the potential health risk posed by endocrine disrupting compounds (ECDs) which can alter the normal function of the endocrine system in wildlife and humans. Potential adverse effects of ECDs have concentrated mainly on reproductive and sexual development, immune function, the nervous system, thyroid function and hormone-related cancers. In addition, the concern of ECDs has been heightened by a number of human and experimental animal studies [1].

Drinking water is a potential source for human exposure to ECDs and is also a target for external measurements [1-3]. Surface waters destined for drinking water can be contaminated by a variety of natural steroid hormones (e.g. estrogens, androgens) as shown by surveys carried out on water samples taken near dairy farms $[7,8]$.

${ }^{*}$ This work was funded by The Department of Agriculture and Rural Development and Henry Lester trust
Furthermore, similar concentrations of these hormones were found in fish within the same water system, providing further evidence of the potential for dairy farm wastewater in contaminating water systems [8].

In 2004, researchers began to study whether steroid hormones excreted by livestock in the UK are reaching streams and rivers where they could be feminising male fish. Related research in the US shows that intensive agriculture and aquaculture are sources of steroids capable of causing endocrine disruption in the aquatic environment [2].

A survey of dairy farm wastewater have demonstrated very high levels of estrogenic compounds compared to piggery or goat farm wastewater [9]. According to a Department for Environment, Food and Rural Affairs (DEFRA) survey of agricultural statistics on predicted estrogenic discharge from both the human and farm animal population in the UK, nearly half of the total UK estrogen discharges were attributed to dairy cattle, even though the population of cattle were only $1 \%$ of the total collective population of humans and farm animals [7]. 
The literature reports that $17 \alpha$-estradiol, $17 \beta$-estradiol, estrone, testosterone $(\mathrm{T})$ and androstenedione (ADT) are the potential contaminants detected in dairy farm waste water $[1,10,13]$. A summary of the levels and locations of these hormones detected in previous studies is presented in Table 1. These hormones have been selected as target compounds for the study of their efficient removal by reactive materials.

The best performers from selected reactive materials, which included granular activated carbon (GAC), zerovalent iron (ZVI) and organoclay, were determined using batch tests. ZVI has previously been used for groundwater remediation in permeable reactive barriers [10]. Granular activated carbon has been shown to have absorption capability for the removal of ECDs [3,11]. Previous studies have demonstrated that the removal efficiencies of GAC were greater than $90 \%$ for many ECDs [11]. Three types of ZVI (Connelly Iron, Gotthart Maier Iron, and Tübingen Iron) were used in the batch test. Although numerous studies have been carried-out on the treatment of organic and inorganic contaminants in water by ZVI [12,13], little research has been conducted on its removal efficiency of naturally occurring hormones. Organoclay has been shown to separate organic pollutant lipophilic 2, 4, 6-trichloroaniline [14]. Research is required to further examine the effectiveness of GAC, ZVI and organoclay, in the removal of estrogens and androgens from contaminated water resource in the environment.

\section{Materials and Methods}

\subsection{RGA Procedure}

An estrogen (MMV-Luc) and androgen responsive cell line (TARM-Luc) were previously produced as described by Willemsen et al., 2004 [15]. For reporter gene assays, cells were seeded in a 96 well plate in $100 \mathrm{ml}$ assay media (DMEM, 10\% hormone depleted serum) and incubated overnight at $37^{\circ} \mathrm{C}$. The next day, $100 \mathrm{ml}$ assay

Table 1. Hormonal contaminants detected in dairy farm wastewater.

\begin{tabular}{ccccc}
\hline \multicolumn{4}{c}{ Target compounds } & \\
\hline \multirow{2}{*}{ Group } & Name & $\begin{array}{c}\text { Detected } \\
\text { concentration }\left(\mathrm{ng} \mathrm{L}^{-1}\right)\end{array}$ & $\begin{array}{c}\text { Sample } \\
\text { location }\end{array}$ & Reference \\
\hline \multirow{2}{*}{ Estrogens } & $17 \alpha$-estradiol & $18.8 \sim 1028$ & & {$[9]$} \\
& $17 \beta$-estradiol & $28.8 \sim 331$ & New & {$[9]$} \\
& Estrone & $41 \sim 3123$ & Zealand & {$[9]$} \\
\hline \multirow{2}{*}{ Androgens } & $\mathrm{T}$ & $840 \pm 75$ & Israel & {$[4]$} \\
& $\mathrm{ADT}$ & 650 & $\mathrm{US}$ & {$[8]$} \\
& & 650 & $\mathrm{US}$ & {$[8]$} \\
\hline
\end{tabular}

media containing reconstituted samples was added to the cells and again incubated at $37^{\circ} \mathrm{C}$ for $24 \mathrm{~h}$ or $48 \mathrm{~h}$ for the estrogen and the androgen assay respectively. The supernatant was then discarded and the cells washed with PBS prior to lysis and luciferase measurement on a luminometer.

RGA data was fitted with the sigmoidal dose-response curve equation to a four-parameter Hill plot, $\mathrm{Y}=\mathrm{Min}$ Response + (Max response-Min response) $/\left(1+\mathrm{X} / \mathrm{EC}_{50}\right)$ $\wedge$ slope of the liner, where $\mathrm{X}$ is the concentration of the testing compounds, Y represent the response of hormonal activity, and the $\min / \max$ response is $0 \sim 100 \%$. The calibration curve was obtained in the presence of an increasing dose of agonist. To compare the hormonal activities of the samples tested, the equivalent standard concentration of each sample was calculated using the light response of samples and $\mathrm{EC}_{50}$ of the calibration curve. Each point was plotted in the standard curve and the level of hormonal activity was determined.

\subsection{Bench Scale Test of Reactive Materials for the Removal of Androgens and Estrogens}

A preliminary batch test to establish the potential of GAC, ZVI and organoclay to remove reported representtative concentrations (as outlined in Table 1) of $\mathrm{T}$ and $17 \beta$-estradiol was performed. $\mathrm{T}$ and $17 \beta$-estradiol were spiked at a concentration of $1000 \mathrm{ng} \mathrm{l}^{-1}$ in HPLC water respectively. A negative and spiked positive control which was not treated by the reactive materials was included. Twenty $\mathrm{ml}$ of spiked water was added to $2 \mathrm{~g}$ of each reactive material in separate universal vials and shaken overnight at room temperature. The sample preparation procedure was based on the Solid phase extraction (SPE) method. Oasis Hydrophilic-Lipophilic Balance (HLB) Plastic cartridge $6 \mathrm{cc} / 200 \mathrm{mg}$ LP (Cat no. 106202) from Water (Milford, US) Oasis HLB cartridges were selected for androgen assay. To avoid estrogenic contamination from plastic cartridges, Oasis HLB Sorbent SPE Glass cartridge $5 \mathrm{cc} / 200 \mathrm{mg}$ LP (Cat no.186000683) were selected for estrogen assay. A solvent series suitable for the elution of hydrophilic and hydrophobic compounds was used. The Oasis HLB cartridges were activated using 3 $\mathrm{ml}$ of tert-butylmethyl ether (Sigma-Aldrich 34498), followed by $3 \mathrm{ml}$ of methanol and then $3 \mathrm{ml}$ of HPLC grade water. Batch-test water samples $(20 \mathrm{ml})$ were loaded onto the cartridges and a vacuum pump was used to assist the flow rate. Each HLB cartridge was washed using $3 \mathrm{ml}$ of $5 \%$ methanol in water (v:v). Retained compounds were eluted using $2 \times 3 \mathrm{ml}$ of $10 \%$ methanol in tert-butylmethyl ether and then dried under a stream of nitrogen gas at $40^{\circ} \mathrm{C}$. The dried extracts were reconstituted in $200 \mu \mathrm{l}$ of methanol. This solution $(10 \mu \mathrm{l})$ was dissolved in $1 \mathrm{ml}$ of assay medium before being tested in 
the RGA.

\section{Results and Discussion}

RGAs have been successfully established with the ability to detect androgens and estrogens. A standard curve was also generated using increasing concentrations of $\mathrm{T}$ and the androgen responsive cell line TARM-Luc (Figure 1). The $\mathrm{EC}_{50}$ obtained was $0.21 \mathrm{ng} \mathrm{ml}^{-1}$. A standard curve was generated using increasing concentrations of $17 \beta$ estradiol and the estrogen responsive cell line MMV-Luc (Figure 2). The $\mathrm{EC}_{50}$ obtained was $0.0012 \mathrm{ng} \mathrm{ml}^{-1}$. These results correspond with the previously published data of Willemsen et al., 2004 [15]. The two assays provide highly sensitive tools for analysis of hormonal activity in the time-scale batch-test.

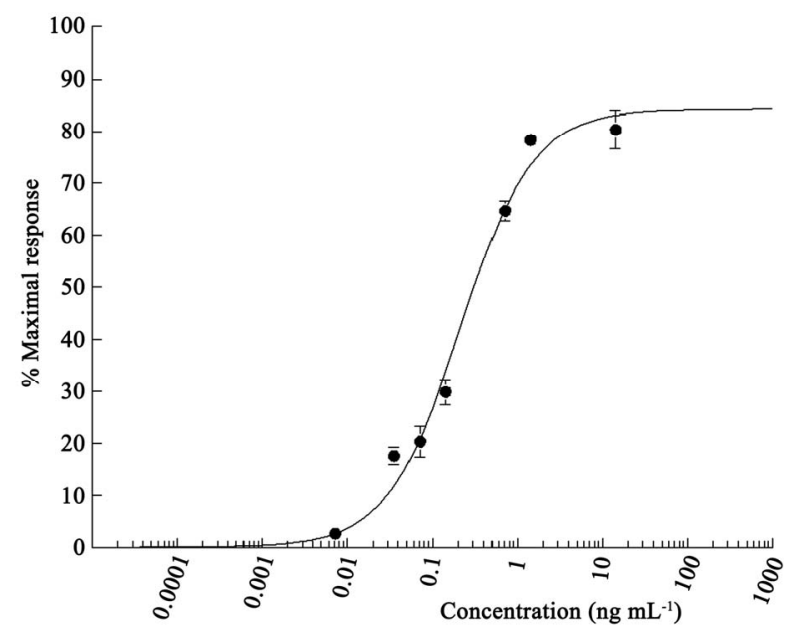

Figure 1. Androgen standard curve obtained using increasing concentrations of $\mathrm{T}, \mathrm{EC}_{50}=0.21 \mathrm{ng} \mathrm{ml}^{-1}$, incubation time $24 \mathrm{~h}$. Error bars show \pm standard deviation.

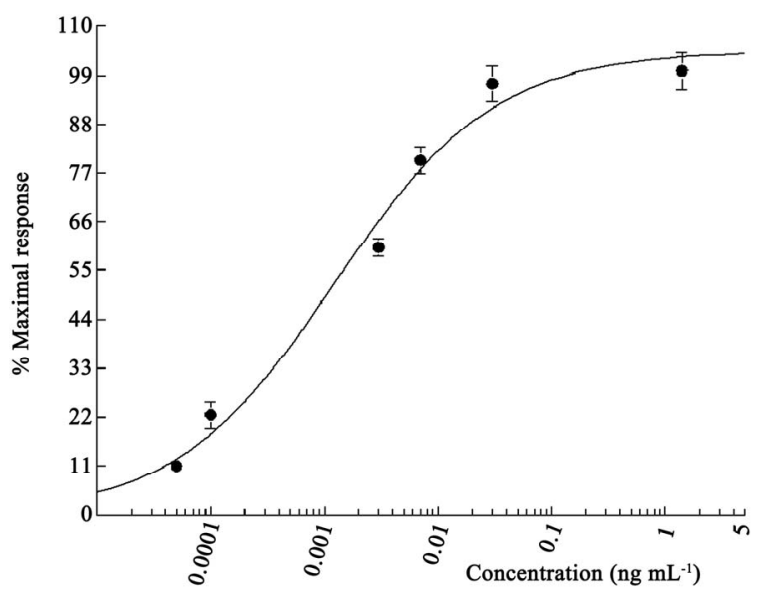

Figure 2. Estrogen standard curve obtained using increaseing concentrations of $17 \beta$-estradiol, $\mathbf{E C}_{50}=0.0012 \mathrm{ng} \mathrm{ml}^{-1}$, incubation time $24 \mathrm{~h}$. Error bars show \pm standard deviation.

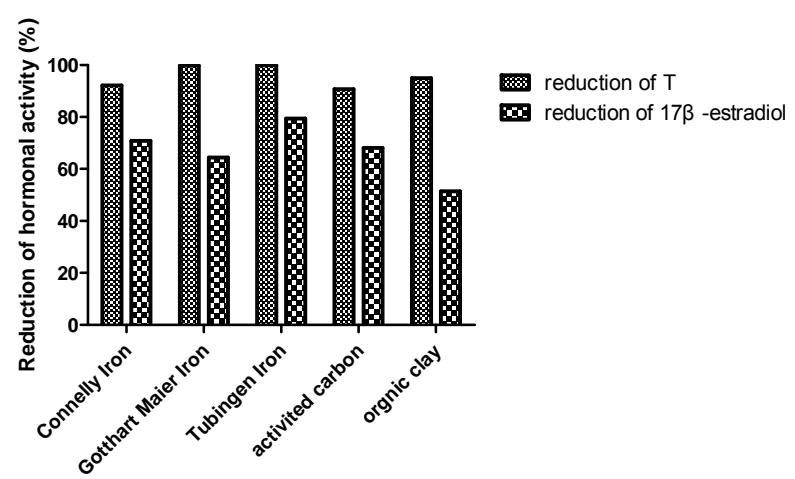

Figure 3. Bench-scale test of reactive materials, reaction time $24 \mathrm{~h}$. Each value was calculated with equation: reduction of hormonal activity $(\%)=($ response of each treated spiked sample- response of positive control)/ response of positive control.

Our preliminary data shows that all reactive materials removed over $92 \%$ of $\mathrm{T}$ and $50 \%$ of $17 \beta$-estradiol from spiked HPLC grade water (Figure 3). Tübingen Iron showed a higher capacity to remove both $\mathrm{T}(99.94 \%)$ and $17 \beta$-estradiol $(79.40 \%)$, compared to the other reactive materials in this study.

To conclude, the previous studies confirm that dairy farm wastewater is a source of EDCs with androgenic and estrogenic activity, capable of contaminating surrounding surface and ground water. In order to reduce the potential environmental risk from dairy farm wastewater an efficient treatment system needs to be employed. The results from this study have confirmed that reactive materials can be used to remove this contaminating hormonal activity. Batch-testing is limited in its ability to select the best performing reactive materials as the dynamic flow condition in environments is more complicated than the rolling flow system used during batchtesting. Future studies could include investigations into how the reactive materials perform under various conditions including hydraulics and temperature. This could then influence the application of the reactive materials.

\section{Acknowledgements}

We would also like to thank Ms Caroline Frizzell from QUB for editing of this manuscript. M.M. is a Chercheur Qualifié from the Belgian F.N.R.S.

\section{References}

[1] T. Damstra, S. Barlow, A. Bergman, R. Kavlock and G. Van Der Kraak, "Global Assessment of the State of Science of Endocrine Disruptors," WHO/IPCS Publishing, 2002.

[2] M. Burke, "UK to Tackle Endocrine Disrupters in Waste- 
water," Environomental Science Technolology, Vol. 38, No. 19, 2004, pp. 362A-363A.

[3] K. Schenck, T. Speth, L. Rosenblum, S. Wendelken, B. Pepich and R. Krishnan, "Evaluation of Drinking Water Treatment Technologies for Removal of Endocrine Disrupting Compounds," SETAC 23rd Annual Meeting, Salt Lake City, 2003.

[4] S. Arnon, O. Dahan, S. Elhanany, K. Cohen, I. Pankratov, A. Gross, Z. Ronen, S. Baram and L. S. Shore, "Transport of Testosterone and Estrogen from Dairy-Farm Waste Lagoons to Groundwater," Environomental Science. Technology, Vol. 42, No. 15, 2008, pp. 5521-5526.

[5] B. M. Blankvoort, R. J. Rodenburg, A. J. Murk, J. H. Koeman, R. Schilt and M. M. J. G. A. Jac, "Androgenic activity in Surface Water Samples Detected Using the AR-LUX Assay: Indications for Mixture Effects," Enviromental Toxicology and Pharmacology, Vol. 19, No. 2, 2005, pp. 163-171.

[6] L. Connolly, C. Kai, J. Tarbin, E. Van der Heiden, M. L. Scippo, M. Muller and C. T. Elliott, "Detection of Glucocorticoid Bioactivity in Bovine Urine Samples Using a Reporter Gene Assay," Analytical Chemica Acta, Vol. 637, No. 1-2, 2009, pp 321-327.

[7] A. C. Johnson, R. J. Williams and P. Matthiessen, "The Potential Steroid Hormone Contribution of Farm Animals to Freshwaters, the United Kingdom as a Case Study," Science of Total Environment, Vol. 362, No. 1-3, 2006, pp. 166-178.

[8] E. P. Kolodziej, T. Harter and D. L. Sedlak, "Dairy Wastewater, Aquaculture, and Spawning Fish as Sources of Steroid Hormones in the Aquatic Environment," Environomental Science Technolology, Vol. 38, No. 23, 2004, pp. 6377-6384.

[9] A. Sarmah, G. L. Northcott, F. D. L. Leusch and L. A.
Tremblay, "A Survey of Endocrine Disrupting Chemicals (EDCs) in Municipal Sewage and Animal Waste Effluents in the Waikato Region of New Zealand," Science of the Total Environment, Vol. 355, No.1-3, 2006, pp. 135-144.

[10] R. B. Powell, R. W. Puls, D. W. Blowes, J. L. Vogan, R. W. Gillham, P. D. Powell, D. Schultz, T. Sivavec and R. Landis, "Permeable Reactive Barrier Technologies for the Contaminant Remediation,” EPA/600/R-98/125, 1998.

[11] S. D. Kim, J. Cho, S. I. Kim, B. J. Vanderford and S. A. Snyder, "Occurrence and Removal of Pharmaceuticals and Endocrine Disruptors in South Korean Surface, Drinking, and Waste Waters," Water Research, Vol. 41, No. 5, 2007, pp. 1013-1021.

[12] Y. Mu, H. Q. Yu, J. C. Zheng, S. J. Zhang and G. P. Sheng, "Reductive Degradation of Nitrobenzene in Aqueous Solution by Zero-Valent Iron," Chemosphere, Vol. 54, No. 7, 2004, pp. 789-794.

[13] S. H. Kang and W. Choi, "Oxidative Degradation of Organic Compounds Using Zero-Valent Iron in the Presence of Natural Organic Matter Serving as an Electron Shuttle," Environmental Science \& Technology, Vol. 43, No. 3, 2009, pp. 878-883.

[14] V. Gianotti, M. Benzi, G. Croce, P. Frascarolo, F. Gosetti, E. Mazzucco, M. Bottaro and M. E. Gennaro, "The Use of Clay to Sequestrate Oranic Pollutants. Leaching Experiments," Chemosphere, Vol. 73, No. 11, 2008, pp. 1731-1736.

[15] P. Willemsen, M. L. Scippo, G. Kausel, J. Figueroa, G, Maghuin-Rogister, J. A. Martial and M. Muller, "Use of Reporter Cell Lines for Detection of Endocrine-Disrupter Activity," Analytical Chimica Acta, Vol. 378, No. 3, 2004, pp. 655-663. 